\title{
Assessment and Suitability Study of Landfills in Jordan, Al-karak using Geographic Information Systems (GIS)
}

\author{
Alsarayreh, H. K. ${ }^{1}$ and Alsarayreh, D. W. ${ }^{2}$ \\ ${ }^{1}$ Department of Geography, Mutah University, Al-karak,Jordan \\ E-mail: Hind1980@mutah.edu.jo \\ ${ }^{2}$ Department of Civil Engineering, Transportation Engineering, The University of Jordan, \\ Amman, Jordan, E-mail: duha_wael@yahoo.com \\ DOI: https://doi.org/10.52939/ijg.v17i3.1899
}

\begin{abstract}
The rate of waste generation is gradually growing due to population growth and urbanization in Jordan, and the increasing population at risk due to forced migration from neighbouring countries. By 2050, waste production will rise to 3.04 billion tons by 70\% since 2016. Specially, that the most sites in Jordan do not comply with the scientific standards. That led this study to aim for creating a suitability map, based on conducting two technical methods and surveying three existing landfill sites located in the target area( AlKarak, Jordan), in addition to suggesting new landfill sites using GIS. 15 criteria were tested socially, economically, and environmentally. Data and GIS data were collected from different local and international websites. Through a predefined scale of sub-criteria, the first suitability map was extracted by equal weight after combining buffering zones and inverse distance weighted (IDW) by applying Algebra map into Arch map. Also, overlay weight was adopted by taking various weights, according to previous studies and authors' point of view. Two suitability maps were extracted and classified into four classes relative to DOS (degree of suitability), mapped out every existing and potential landfills. The results of the equal weight suitability map showed that $45 \%$ of the area is inadequate and $7 \%$ is fairly suitable for landfill, whereas different weight suitability map showed that only $4 \%$ is inadequate and $6 \%$ is fairly suitable for landfill. Each method showcased different areas, this indicates weight plays a major role, and the low effects of soil weight may be a result of the negative difference ratio (41\%) between the two approaches in an inadequate ranking. This study is important because it provide necessary data on the viability of new dumps site based on important factors, leading to future research and new techniques. Improved landfills suitability will positively influence the economies of Jordan and the municipal economies. Finally, the authors recommend a long-term sustainability policy to counter the harmful impact of burying.
\end{abstract}

\section{Introduction}

Landfills of the Municipal Solid Waste(MSW) is the most popular disposal method in Jordan and it's a common method in Turkey (Sener et al., 2010). However, choosing sites for landfill demand stringent requirements that take specific criteria into account (Vasiljevic et al., 2012). Decisions should therefore be addressed based on measurements that serve the decision-makers' purposes (Saaty, 2008). Choosing landfill sites is a considerably complex task as it directly affects the environment and public health (Akbari, et al., 2008). Migration from country side into urban areas is the main cause of over population and high urbanization rates in addition to the increasing of services and employment opportunities in cities, especially in developing countries, which in turn resulted in a high MSW rate (Aljaradin, 2010). Municipal solid waste is classified as solid and semi-solid materials derived from homes and residential complexions, beside other waste materials related to the prior in terms of its nature and composition (offices, public institutions, commercial activities, etc.) (Jordan Green Buildings Council 2016).

MSW is considered as an expression of changes in lifestyle and social trends, especially with their rapid increase in China (Pla, 2015). The administration of Jordan Lacks any current legal waste management framework . About 2 million tonnes of MSW in Jordan are generated each year and buried into insalubrious landfills (EcoMENA, 2012). Dumping sites in Jordan have serious impacts on the environment and natural resources that their administrations do Not take into account. Typically, many waste disposal sites receive medical or industrial waste without treatment, and in other situations, waste gets incinerated out in the open, which damages the entire ecosystem.

The correct selection and maintenance of appropriate sites lead to a sustainable environment, therefore, Geographic Information Systems (GIS) 
has been used in study preparations that arerelated to assessing existing sites and how to operate them with high efficiency and lower cost. The study also addressed GIS utilization with several criteria to be used for the evaluation of acceptable dumping sites. Many authors have used GIS technology to assess possible landfill locations and a lot of researches results show that GIS has been commonly applied in waste management systemsaround the world, (Shahabi et al., 2014) focused on GIS through 13 layers to decide on an acceptable site, the chosen technical methods are Boolean, Weighted Linear Combination (WLC), Analytical Hierarchy Process (AHP). The created models illustrate that Boolean logic had lower credibility and flexibility rates than WLC and AHP. Decision-making skills have improved due to a wide variety of classification and practical practice that can be carried out to minimize economic and environmental costs. The WLC approach uses weighting to allow the decisionmakers to use the key variables that would have the greatest effect on choosing the best location. (Yesilnacar et al., 2011) revealed that the conventional expert-based approaches have not always been able to test limitations at the same time, and therefore map replication is restricted as parameter maps are evolving rapidly over time. As the authors used GIS with Multi-Criteria Decision Analysis (MCDA) to select possible landfill location and compared to the original one. (Mussa et al., 2019) used AHP to obtain weights for each 10 selected criteria; this weight derivation method was used to compare two parameters at a time based on expert judgment and a pair-wise evaluation matrix. The outcomes of this study proved that by using AHP and GIS for the selection of suitable sanitary landfill sites; thus reducing environmental and human health issues.

\section{Background}

In Jordan, the effect of waste is more severe due to financial and natural resources (Al-Ansari et al., 2012). The studied city is shown in Figure 1; it suffers from the issue of not implementing all the criteria in selecting the most suitable landfill site. There are three solid waste dumps in the city, the largest of which is the Allajoun landfill, 488 acres, located 10 kilometers on the east side of Al-Karak on the Al-Karak-Al-Qetraneh road. It was established in 1996 and expired in 2006. This landfill is considered to be an environmental issue, presents many dangers, such as the spread of many infectious and dangerous diseases, since it emits unpleasant odors due to the regular burning of 150 tons in average of waste inside the landfill, which harms travelers on the main road that links the city to the desert road (road linking the city to the capital).
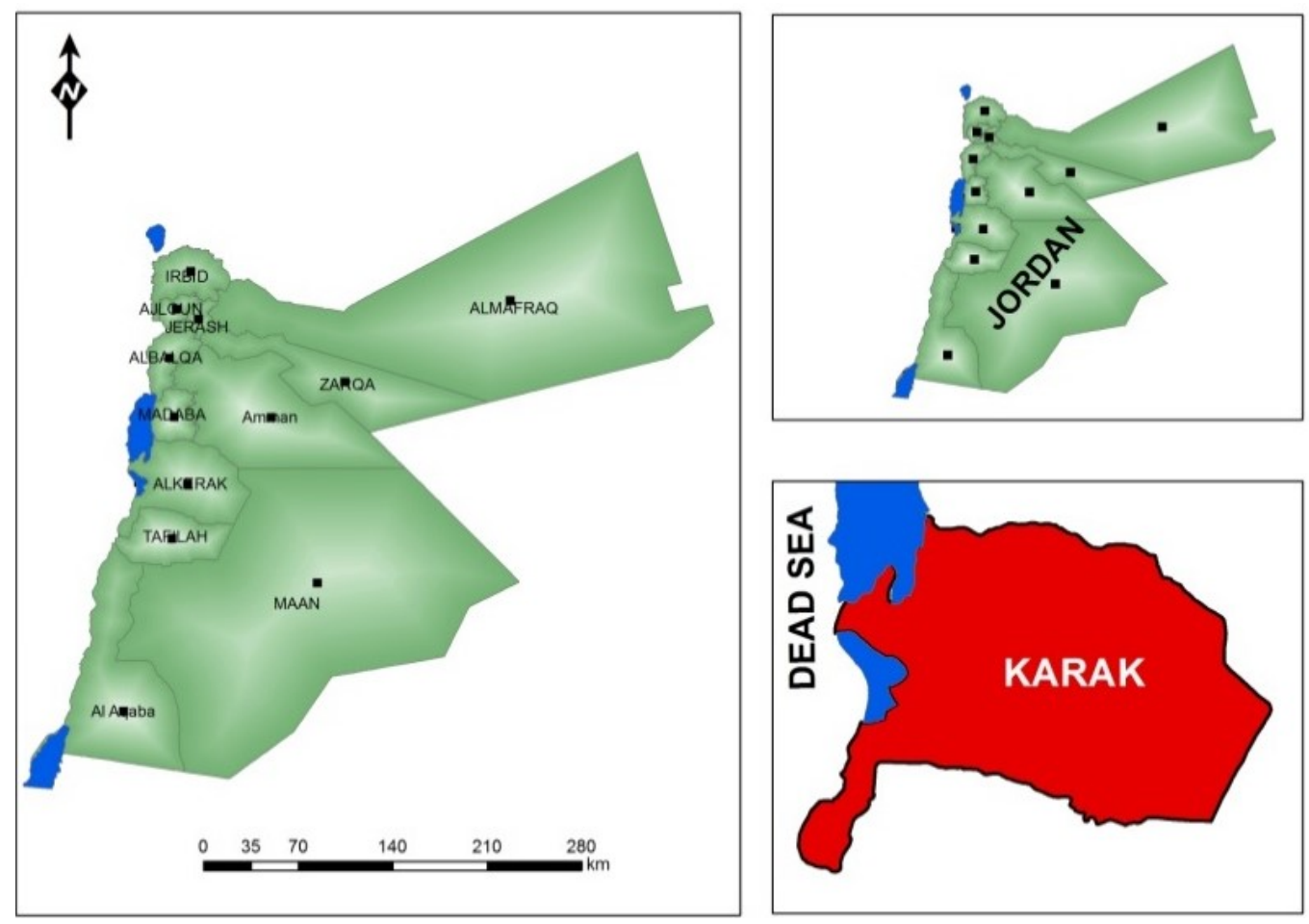

Figure 1: Location of Al-Karak City in Jordan 
Albreka and Alsomer landfills are located in AlAghwwar Al-Janoobieh, where they represent sanitary and environmental issues due to the process of direct waste burning which produces toxic gasses are dispersed by wind. According to Jerie, (2017) researcher combined both quantitative and qualitative approaches. The author depended on the basic idea that such an arrangement makes more systematic data use than the distinctive compilation and analysis of quantitative and qualitative data separately. The major steps had implemented digitizing, buffering, overlaying, suitability maps against studied parameters. The results of the previous study show that GIS and remote sensing (RS) are invaluable tools for urban planning and problem-solving in evaluating the suitability of the existing dumpsites.

Many researchers have used weighted overlay analysis in GIS for selecting multiple functions to achieve corresponding results. Kuru et al., 2018 applied weight overlay to study the suitability of existing municipal landfill sites using GIS. The score of sub-criteria were determined (10\% slope, $8 \%$ aspect, $13 \%$ land use, $7 \%$ erosion, $10 \%$ hydrology, 11\% geology, 10\% land use capability, $8 \%$ proximity of built-up environment, $14 \%$ proximity of transportation, and $10 \%$ proximity of urban facilities). The results of used weight overlay showed that the suitable areas were located in the northeast and northwest regions in the studied city and these results give standards for planning studies in futures. Carvalho et al., 2007 used three methods in GIS to compute vegetation vulnerability models. The first approach introduced is weight overlay, and the authors clarify reasons for using this strategy because they find it simple and the relative weight can describe the importance for each included variable. Meirelles et al., 2007 note that the use of weighted overlays requires the use of expert information and the modification of each variable's intrinsic characteristics in the model. The other approaches used by Carvalho et al., 2007 are fuzzy logic and neural networks. Fuzzy-based strategies are similar to weight overlay in modeling, with the advantage of the more flexible rules for the combination of the second method but the interval is between $[0,1]$ for class values. The authors defined the weights through convex sum because the effects of the measures are not similar. For example, the subgroups of $A_{1} \ldots A_{k}$, and non-negative weights of $\mathrm{w}_{1} \ldots \mathrm{w}_{\mathrm{k}}$ so the combination is shown below in Equation 1:

$$
U A \Delta \sum w j U A j
$$

Where:

$\mathrm{U}_{\mathrm{A}}=$ Fuzzy membership level

$\mathrm{w}_{\mathrm{j}}=\operatorname{Weight}\left(\sum w j=1\right)$

This research will therefore concentrate on identifying the criteria for proper planning of solid waste landfills using algorithm techniques to design suitability models and to propose new places based on a selection of conditions and criteria. This research aims to achieve the following goals:

1. Are the current landfill sites in Karak Governorate suitable?

2. Are there standards and requirements for selecting suitable sites for landfills?

3. Where are the best locations in Al-Karak to suggest new landfills according to international standards and terms?

\subsection{Literature Review}

Ekmekcioglu et al., (2010) have conducted a fuzzy TOPSIS method to suggest disposal sites for the MSW in Catalca in Istanbul. A set of criteria were optimized as pollution, cost, feasibility, reliability, energy recovery, and emission and waste levels to find the best disposal MSW method. The authors relied on specific alternatives such as composting, and incineration of refuse-derived fuel (RDF). Weights assessment was carried out by the method of the Analytic Hierarchy Process (AHP). The results of the study found that RDF is the best alternative disposal method and the significance of weights when assessing the optimal location of dumpsites. Another study in Sekondi-Takoradi city in Ghana has used the same approach of the previous study of Multi-criteria Evaluation (MCE) and Fuzzy Logic method in order also to determine the suitable landfill sites where the analysis was restricted to criteria which are especially relevant for the site (Bilintoh and Stemn, 2015). A study focused on the AHP method and GIS to analyse eight criteria (geology, distance from settlements, distance from road networks, distance from Water bodies, vegetation, slope, elevation and aspect) for landfill selection in the municipality of Nevesinje in Srpska. The results of the suitability index show that $67 \%$ of the land belongs to the restricted area, $11 \%$, $6.1 \%$, and $5.9 \%$ belong to low, moderate, high suitability respectively, and very high suitability associated with $10 \%$ of the land. Furthermore, the authors conclude that more criteria should be investigated before choose the final sites, and this will be better to ensure an optimal location for their final landfill location (Sekulovic and Jakovljevic, 2016). 
Results of a study conducted in Bardaskan city, Iran has motivated municipality officials to select the best location of landfills among several locations. The authors added that this study is useful for decision-makers to make appropriate decisions that reduce costs in economic and environmental standards as half of the study $(51.97 \%)$ area was not suitable and just (7.8\%) is suitable for the landfill site using Fuzzy Logic with GIS analyzing (Khorram et al., 2014).

Each region has certain factors that satisfy its nature so is not required to consider all the combined factors where Younes et al., 2015 results study shown that the two most influential factors to achieve preferences on landfill site requirements are the topology of the land and surface water distance. Manoiu et al., 2013 have taken Euclidean distance to eliminate buffer zones to deiced landfill suitability in Prahova County, Romani. Barakat et al., 2017 investigated suitable landfill sites using GIS methods for multi-criteria evaluations. They categorized municipal landfill locations into five groups ranging from not suitable to highly suitable. Their study revealed that $54 \%$ of the study area was not suitable for landfill sites and just $10 \%$ is highly acceptable for disposal. Also, Pasalari et al., 2019 have examined 15 criteria in Iran as same as some of the studied criteria in this research with different ones as a protected area, fault in an environmental group, airport, village, infrastructure, and historical area. Alanbari et al., 2014 investigated criteria as pipes, energy lines, oil pipes, fluid gas pipes, and railways, etc to decide the best landfill sites.

\subsection{Materials}

The first stage of preparing the suitability map was to define the criteria to select the best sites for waste disposal in Al-Karak province. 15 criteria were selected according to the public local authorities' guidelines in Jordan and comparative research analysis of other quality criteria for landfills projects. The criteria contain residential and main roads, green areas, existing dumps, water bodies, soil, slope, land use, rain, temperature, and aspect. The digital form of the analytical approach was adopted in GIS (ArcGIS 10.3) through digitizing every criterion into a layer in raster form. The buffer zone was adopted to reclassify the criteria based on distance in a polygon shape. The interpolated raster for such criteria was implemented according to the IDW technique. Spatial analysis tools in GIS were adopted using Map Algebra to establish the integrated model of suitability map.

\subsection{Data}

The data was collected from official institutions as the Royal Jordanian Geographic Centre, Ministry of Agriculture, Ministry of Water, Ministry of Public Works, and Natural Resources Authority related to the study. Sources of data varied depending on the minor field of sub-criteria as shown in Tables 1-4.

Table 1: Classification of economic and social criteria by different factors

\begin{tabular}{|c|c|c|c|c|c|}
\hline Minor Criteria & No. & Source & Minor criteria & Scale & DOS \\
\hline \multirow{12}{*}{$\begin{array}{c}\text { social } \\
\text { and economic }\end{array}$} & \multirow[t]{2}{*}{1} & \multirow{7}{*}{$\begin{array}{l}\text { The European } \\
\text { Bank for } \\
\text { Reconstruction and } \\
\text { Development } \\
\text { (EBRD, 1991) }\end{array}$} & \multirow{2}{*}{$\begin{array}{l}\text { Distance from } \\
\text { residential areas }\end{array}$} & \multirow[t]{2}{*}{$>1500 \mathrm{~m}$} & $(1)<1500 \mathrm{~m}$ \\
\hline & & & & & (4) $>1500 \mathrm{~m}$ \\
\hline & \multirow[t]{2}{*}{2} & & \multirow{2}{*}{$\begin{array}{l}\text { Distance from main } \\
\text { roads and streets }\end{array}$} & \multirow[t]{2}{*}{$>500 \mathrm{~m}$} & $(1)<500 \mathrm{~m}$ \\
\hline & & & & & (4) $>500 \mathrm{~m}$ \\
\hline & \multirow[t]{3}{*}{3} & & \multirow{3}{*}{$\begin{array}{l}\text { Distance from } \\
\text { agricultural land }\end{array}$} & \multirow{3}{*}{$\begin{array}{l}\text { It is safer to stay out } \\
\text { of arable land and to } \\
\text { choose landfill } \\
\text { operation on low- } \\
\text { value land }\end{array}$} & (1)Arable land \\
\hline & & & & & \\
\hline & & & & & $\begin{array}{l}\text { (4) Non Arable } \\
\text { land }\end{array}$ \\
\hline & \multirow[t]{2}{*}{4} & \multirow{5}{*}{$\begin{array}{c}\text { Department for } \\
\text { Environment, Food } \\
\text { and Rural Affairs, } \\
2010\end{array}$} & \multirow{2}{*}{$\begin{array}{l}\text { Distance from green } \\
\text { areas and gardens }\end{array}$} & \multirow{2}{*}{$\begin{array}{l}\text { It is safer to stay } \\
\text { away from green } \\
\text { lands and gardens to } \\
\text { make better use of } \\
\text { them }\end{array}$} & (1)Green Areas \\
\hline & & & & & $\begin{array}{c}\text { (4) Nom Green } \\
\text { Areas }\end{array}$ \\
\hline & \multirow[t]{3}{*}{5} & & \multirow{3}{*}{$\begin{array}{l}\text { Distance from existing } \\
\text { dumps }\end{array}$} & \multirow{3}{*}{$\begin{array}{l}\text { Existing landfills } \\
\text { should be kept away } \\
\text { from and choose } \\
\text { locations close to } \\
\text { waste generation } \\
\text { centers to reduce cost } \\
\text { and time }\end{array}$} & $(1)<1500 \mathrm{~m}$ \\
\hline & & & & & \\
\hline & & & & & (4) $>1500 \mathrm{~m}$ \\
\hline
\end{tabular}


Table 2: Classification of environmental by different factors

\begin{tabular}{|c|c|c|c|c|c|}
\hline Minor Criteria & No. & Source & Minor criteria & Scale & DOS \\
\hline \multirow{7}{*}{ Environmental } & \multirow[t]{2}{*}{6} & \multirow{7}{*}{$\begin{array}{c}\text { Alshmoli Amman } \\
\text { plan(Greater Amman } \\
\text { Municipality, 2007- } \\
\text { 2008) }\end{array}$} & \multirow{2}{*}{$\begin{array}{c}\text { Distance from valleys and } \\
\text { torrents }\end{array}$} & \multirow[t]{2}{*}{$>100 \mathrm{~m}$} & $(1)<100 \mathrm{~m}$ \\
\hline & & & & & $(4)>100 \mathrm{~m}$ \\
\hline & \multirow[t]{2}{*}{7} & & \multirow[t]{2}{*}{ Distance from springs } & \multirow[t]{2}{*}{$>360 \mathrm{~m}$} & $(1)<360 \mathrm{~m}$ \\
\hline & & & & & $(4)>360 \mathrm{~m}$ \\
\hline & 8 & & Distance from dams & $>360 \mathrm{~m}$ & $\begin{array}{l}(1)<360 \mathrm{~m} \\
4)>360 \mathrm{~m}\end{array}$ \\
\hline & \multirow[t]{2}{*}{9} & & \multirow[t]{2}{*}{ Distance from wells } & \multirow[t]{2}{*}{$>360 \mathrm{~m}$} & $\frac{(4)>360 \mathrm{~m}}{(1)<360 \mathrm{~m}}$ \\
\hline & & & & & $(4)>360 \mathrm{~m}$ \\
\hline
\end{tabular}

Table 3: Classification of geology and morphology by different factors

\begin{tabular}{|c|c|c|c|c|c|}
\hline Minor Criteria & No. & Source & Minor criteria & Scale & DOS \\
\hline \multirow{12}{*}{$\begin{array}{l}\text { Geology and } \\
\text { morphology }\end{array}$} & \multirow[t]{4}{*}{10} & \multirow{4}{*}{$\begin{array}{c}\text { Basel Convention } \\
\text { Regional Center For } \\
\text { Training \& } \\
\text { Technology Transfer } \\
\text { For The Arab States } \\
\text { In Egypt (BCRC- } \\
\text { CAIRO, 2005a) }\end{array}$} & \multirow{4}{*}{$\begin{array}{l}\text { Topography and } \\
\text { slope ratio }\end{array}$} & \multirow{4}{*}{$\begin{array}{l}\text { Low-slope areas } \\
\text { are preferred with } \\
\text { ideal ratios of 1- } \\
5 \% \text { and not } \\
\text { appropriate for } \\
\text { more than } 25 \%\end{array}$} & (1) $>25 \%$ \\
\hline & & & & & (2) $10-25 \%$ \\
\hline & & & & & (3) $6-10 \%$ \\
\hline & & & & & $(4) 1-5 \%$ \\
\hline & \multirow[t]{4}{*}{11} & \multirow{8}{*}{$\begin{array}{c}\text { (Yazdani et al., } 2015 \\
\text { and Eskandari et al., } \\
\text { 2015) }\end{array}$} & \multirow[t]{4}{*}{ Soil } & \multirow{4}{*}{$\begin{array}{l}\text { Preferred soil with } \\
\text { low permeability }\end{array}$} & (1)>25\% \\
\hline & & & & & (2)12.7-25\% \\
\hline & & & & & (3) $2-12.7 \%$ \\
\hline & & & & & $(4)<2 \%$ \\
\hline & \multirow[t]{4}{*}{12} & & \multirow{4}{*}{$\begin{array}{l}\text { Geology of the } \\
\text { region }\end{array}$} & \multirow{4}{*}{$\begin{array}{l}\text { Rock and desert } \\
\text { areas are preferred }\end{array}$} & (1)Holocene \\
\hline & & & & & (2)Sandstone \\
\hline & & & & & (3)Limestone \\
\hline & & & & & (4)Basalt \\
\hline
\end{tabular}

Table 4: Classification of climatic by different factors

\begin{tabular}{|c|c|c|c|c|c|}
\hline Minor Criteria & No. & Source & Minor criteria & Scale & DOS \\
\hline \multirow{12}{*}{ climatic } & \multirow[t]{4}{*}{13} & \multirow{8}{*}{$\begin{array}{l}\text { Alshmoli Amman } \\
\text { plan(Greater } \\
\text { Amman } \\
\text { Municipality, 2007- } \\
\text { 2008) }\end{array}$} & \multirow[t]{4}{*}{ Amount of rain } & \multirow{4}{*}{$\begin{array}{l}\text { Preferred dry areas } \\
\text { with less rain for a } \\
\text { lower level of } \\
\text { succulents }\end{array}$} & $(1)>350$ \\
\hline & & & & & (2)25-300 \\
\hline & & & & & (3)300-350 \\
\hline & & & & & (4)50-250 \\
\hline & \multirow[t]{4}{*}{14} & & \multirow[t]{4}{*}{ Temperature } & \multirow{4}{*}{$\begin{array}{l}\text { Preferably high } \\
\text { temperature areas } \\
\text { where the amount of } \\
\text { evaporation is high }\end{array}$} & $(1)>32$ \\
\hline & & & & & (2)32-36 \\
\hline & & & & & (3)36-38 \\
\hline & & & & & (4)38-42 \\
\hline & \multirow[t]{4}{*}{15} & \multirow{4}{*}{$\begin{array}{l}\text { (BCRC-CAIRO, } \\
2005 \mathrm{~b})\end{array}$} & \multirow{4}{*}{$\begin{array}{l}\text { Mountain slopes } \\
\text { direction }\end{array}$} & \multirow{4}{*}{$\begin{array}{l}\text { Areas opposite to } \\
\text { wind direction are } \\
\text { preferred, } \\
\text { particularly in areas } \\
\text { close to the } \\
\text { population } \\
\end{array}$} & (1) 202.5 \\
\hline & & & & & (2) $160-202.5$ \\
\hline & & & & & (3)22.5-160 \\
\hline & & & & & (4)0-22.5 \\
\hline
\end{tabular}

\subsection{Study Area}

The study area Al-Karak city is located in the south of Jordan as shown in Figure 2. It is located between two longitudes $35^{\circ} 19^{\prime} 48^{\prime \prime}$ and $36^{\circ} 13^{\prime} 12^{\prime \prime}$ and between

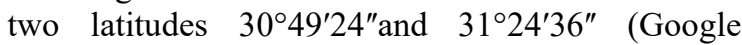
Earth). The total area of the Governorate is 3495 $\mathrm{km} 2$ according to (The Department of Statistics, Jordan). The Governorate has faced a rapid population increase due to economic activities and forced migration, the population of the Governorateis 316,629 people with an average annual growth rate of $3.7 \%$ between 2004 and 2015 . It consists of seven states and three districts. It is limited to Amman (capital of Jordan), and threeGovernorates: Madaba, Tafila, and Ma'an and to the Dead Sea at the west. The Governorate consists of seven states and three districts. There are three existing landfills received from Al-karak municipality:

(i) Albreka dumpsite located in Gore AlMazraa District in Al-Aghwwar Al-Janoobieh 
with coordinates $\left(35^{\circ} 29^{\prime} 15.30^{\prime \prime} \quad \mathrm{E}\right.$; $\left.31^{\circ} 14^{\prime} 3.07^{\prime \prime} \mathrm{N}\right)$.

(ii) Alsomer dumpsite located in Al-Aghwwar Al-Janoobieh with coordinates $\left(35^{\circ} 28^{\prime} 37.67^{\prime \prime} \mathrm{E} ; 30^{\circ} 58^{\prime} 55.81^{\prime \prime} \mathrm{N}\right)$. (iii) Allajoun which located in Allajoun area in Al-Qetraneh with coordinates $\left(35^{\circ} 56^{\prime} 32.06^{\prime \prime} \mathrm{E}\right.$; $\left.31^{\circ} 13^{\prime} 16.28^{\prime \prime} \mathrm{N}\right)$, as seen in Figure 3. All locations are projected in WGS84.

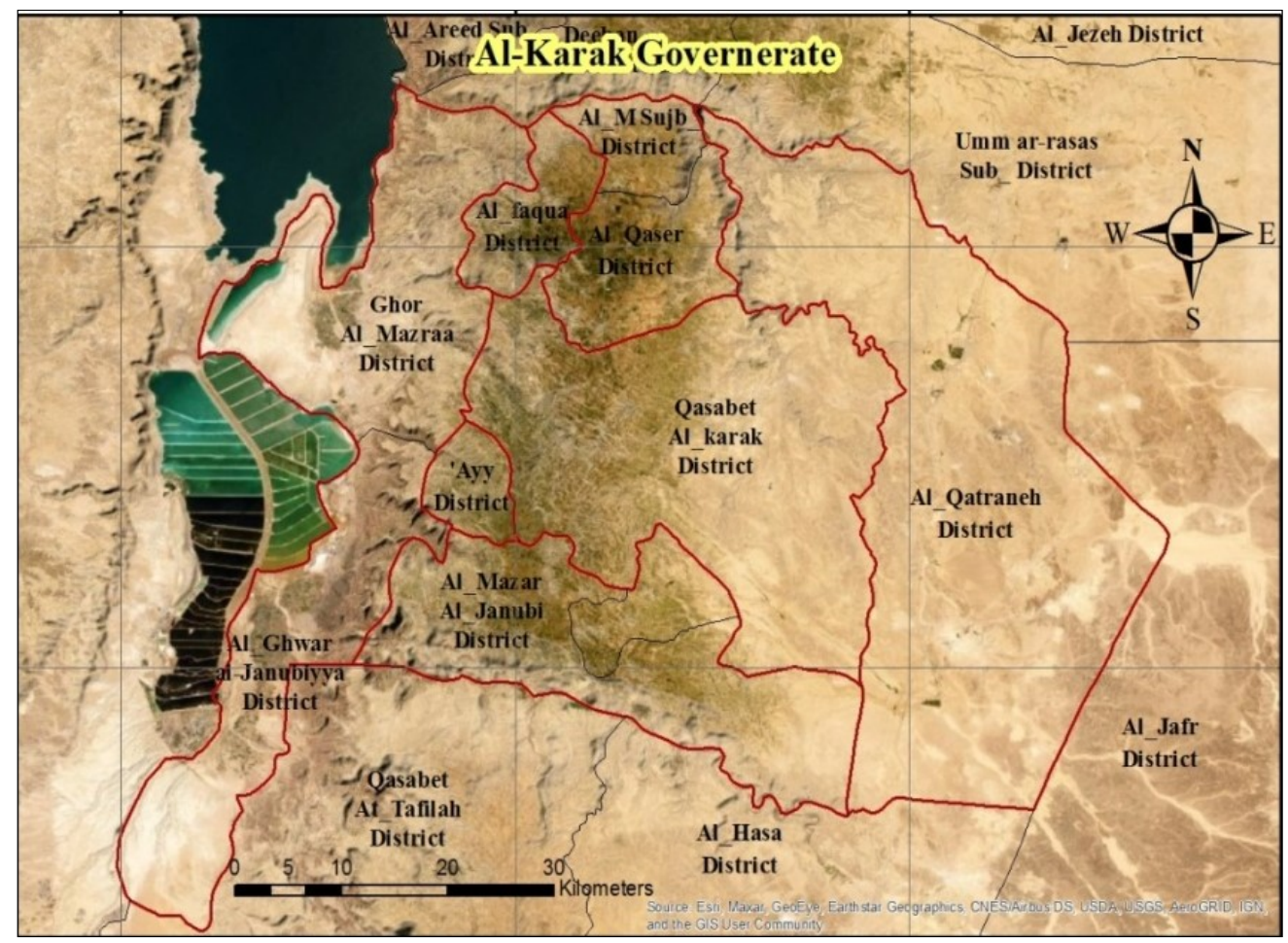

Figure 2: Location of Al-Karak City with main states inside it

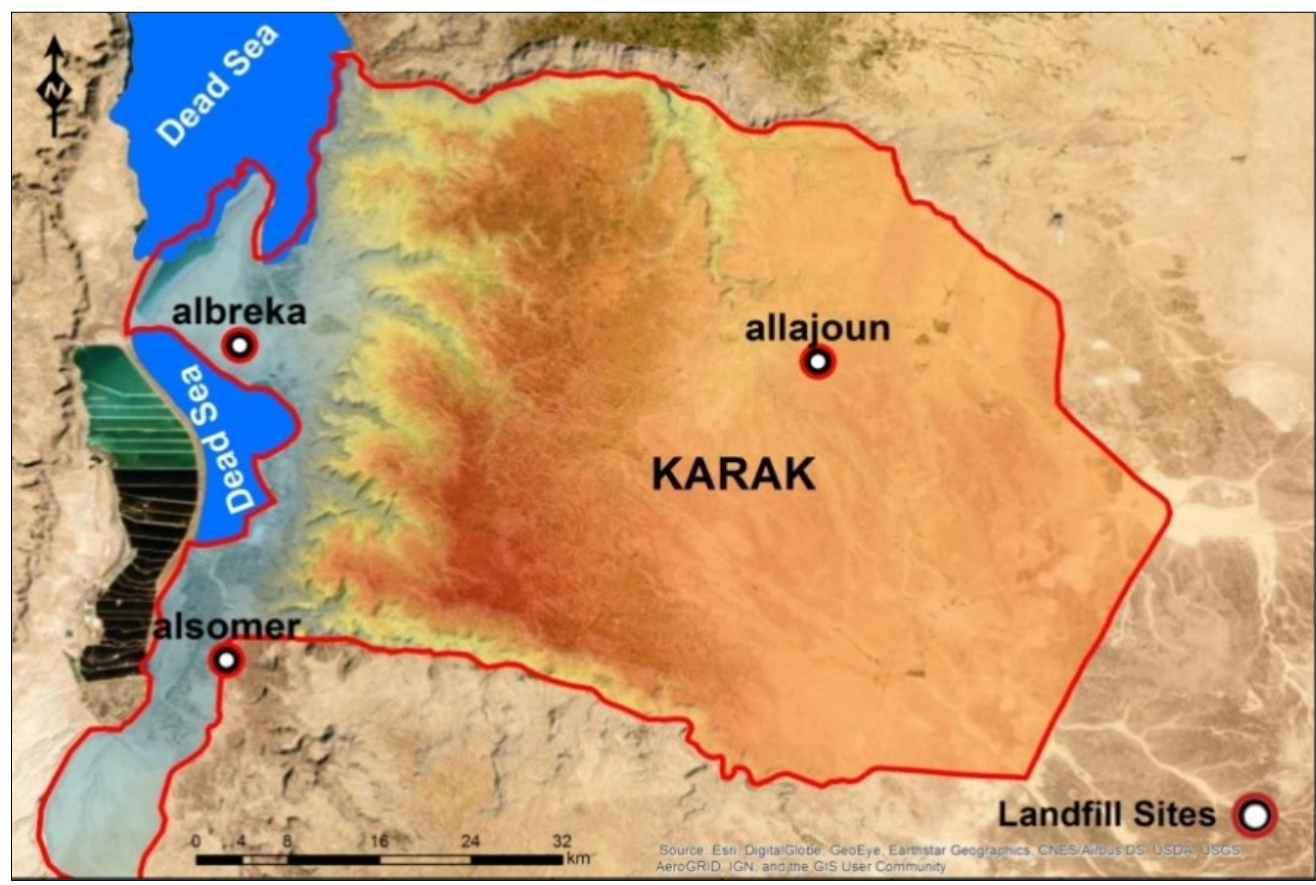

Figure 3: Location of existing dumpsites in Al-Karak 


\section{Methodology}

The study aims to comprehend the relative significance of each sub-criterion in the identification of the most possible sites for landfills. Respective maps and information identified criteria were taken from various related organizations. All of these maps were digitized and converted from vector to raster form as polygon shapes as presented in Figure 4. Population sites and roads were extracted from the topographic map. Streams and springs were extracted from Spatial Analyst Tool in
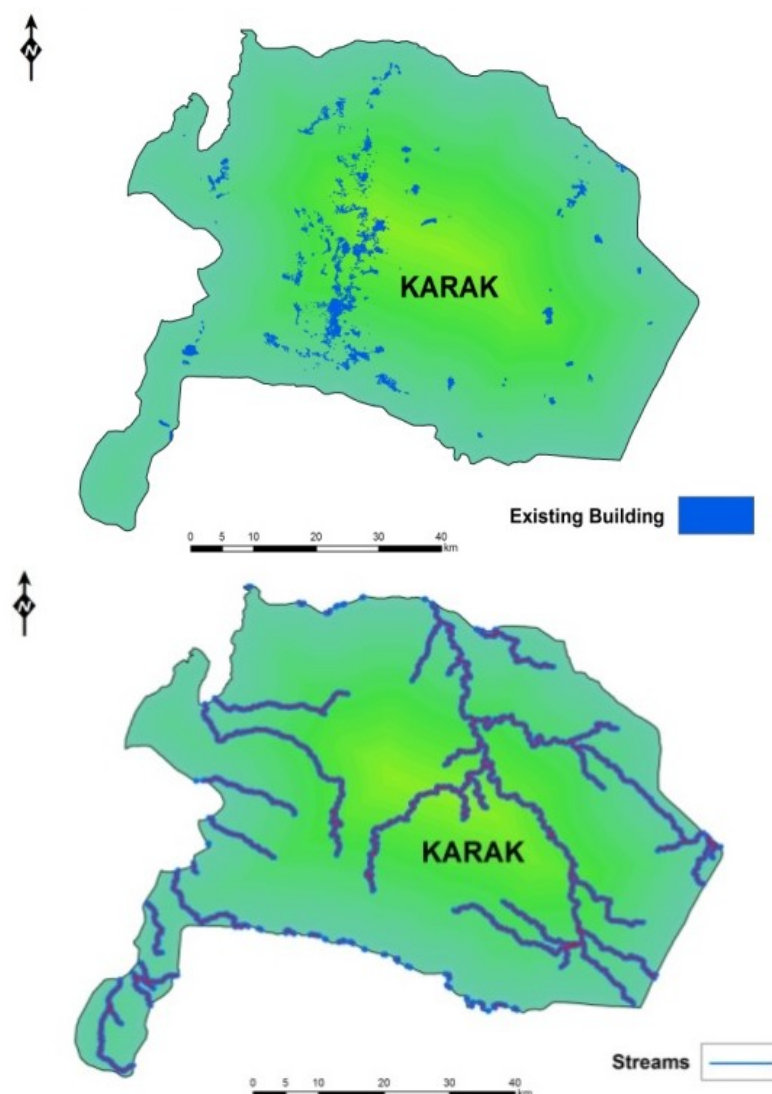

$\hat{\psi}$

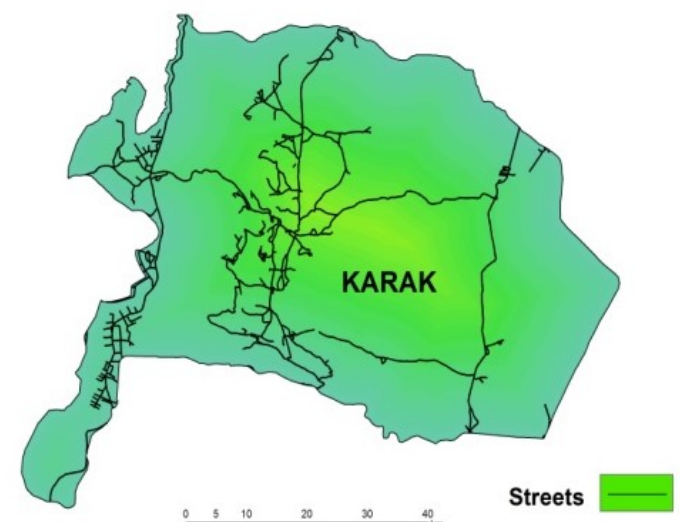

$\hat{\psi}$
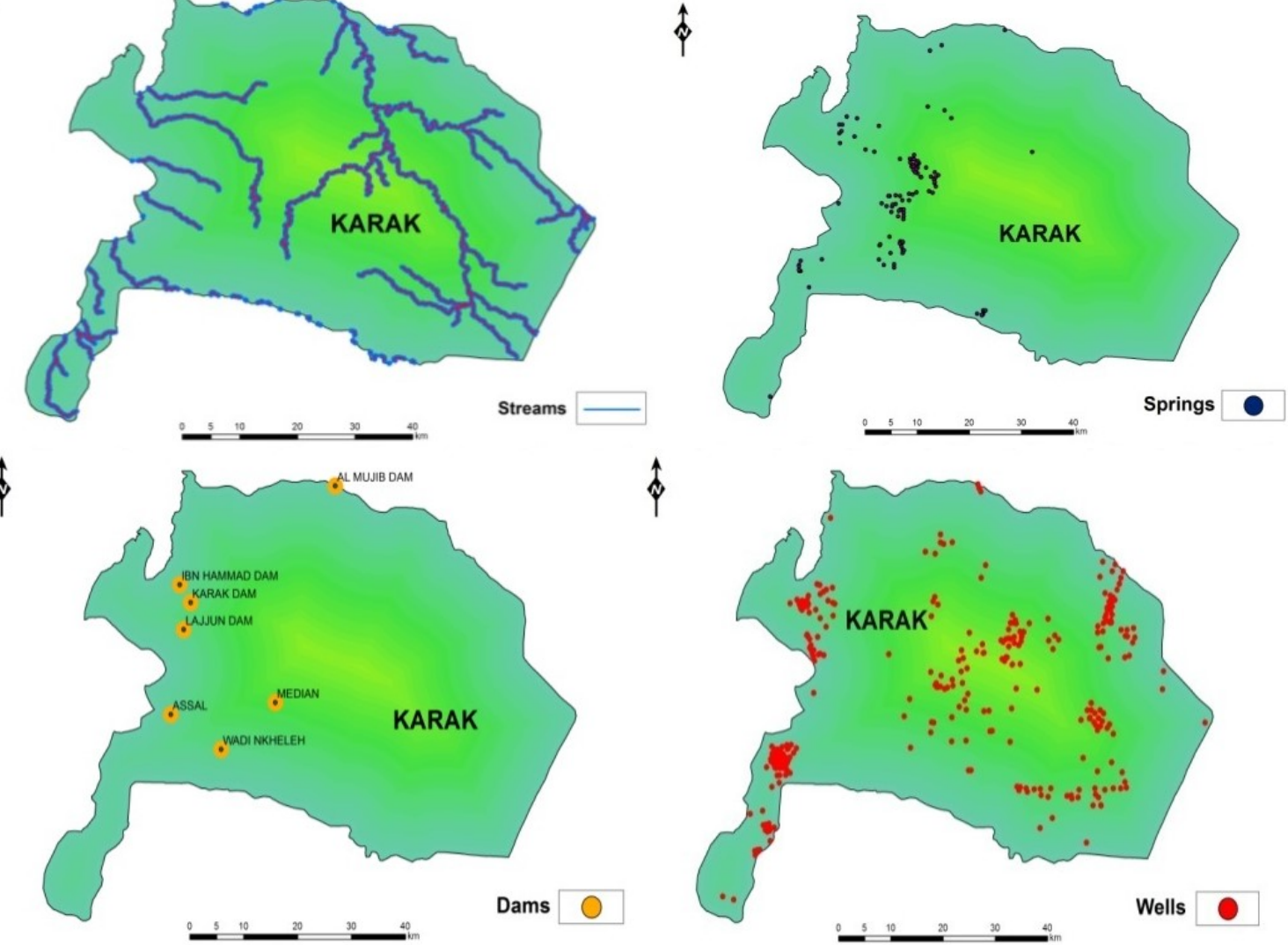

Figure 4: Raster maps of all criteria (continue next page) 
 \\ 20}
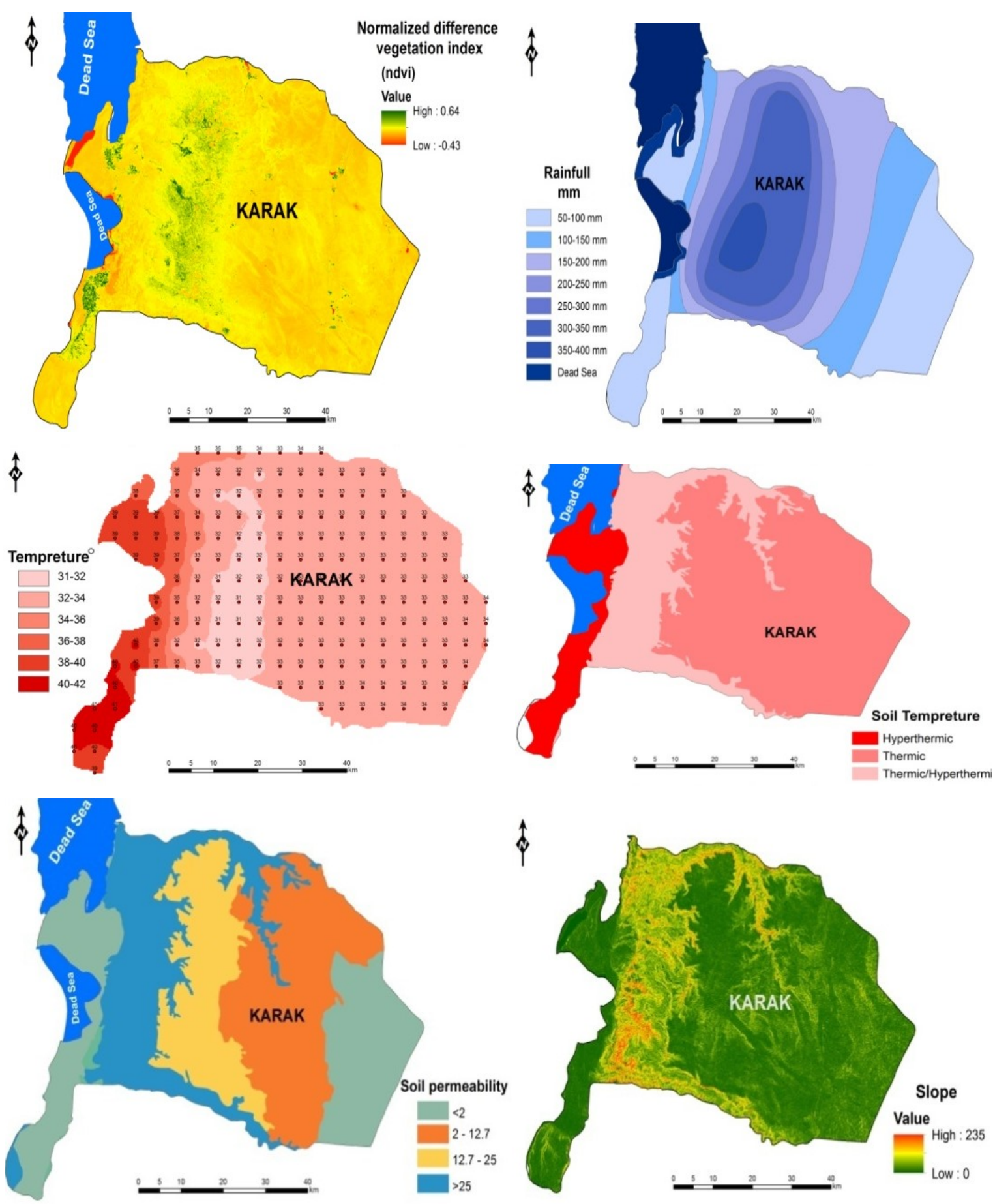

Figure 4: Raster Maps of All Criteria (continue next page) 


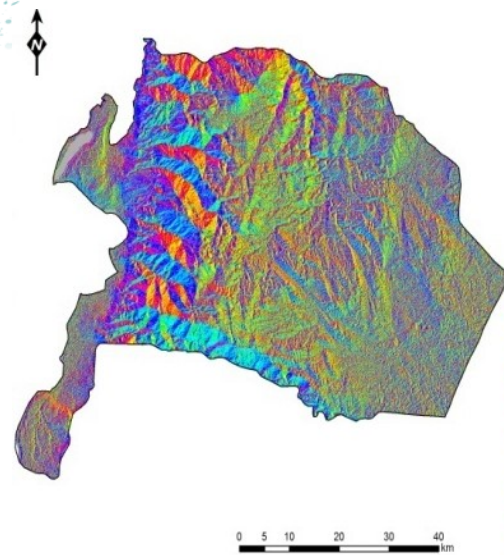

$\hat{N}$
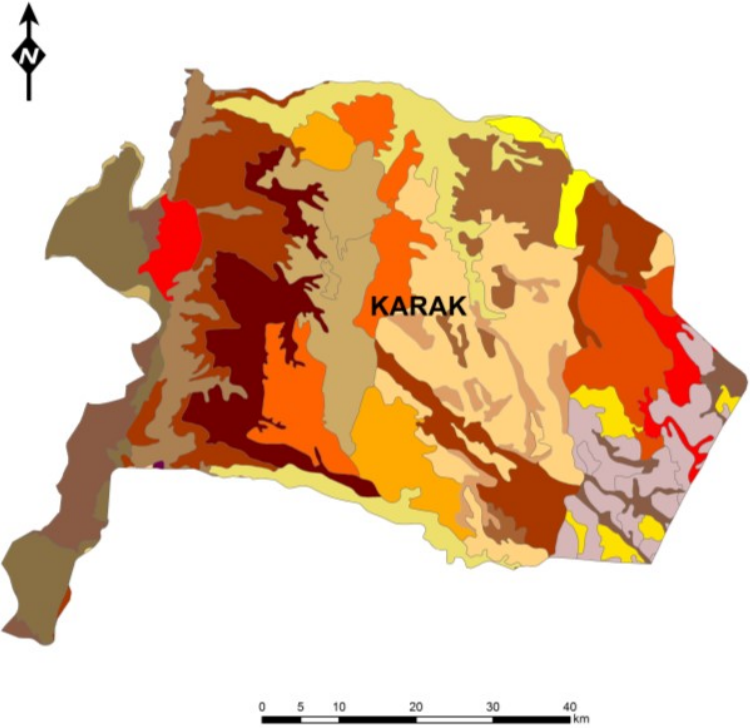

Figure 4: Raster maps of all criteria

Table 5: Soil permeability classes

\begin{tabular}{|l|c|}
\hline \multicolumn{1}{|c|}{ Soil permeability classes } & Permeability Rates (cm/hour) \\
\hline Very Slow-Slow & $<2 \%$ \\
\hline Moderately Slow-Moderately Rapid & $2-12.7 \%$ \\
\hline Moderately Rapid-Rapid & $12.7-25 \%$ \\
\hline Very Rapid & $>25 \%$ \\
\hline
\end{tabular}

The main soil classes are also classified into 21 types. The slope of the area was extracted from the Digital Elevation Model (DEM) in ArchToolbox and taken from 0 (low inclination) to 235 (high inclination). Another sub-criteria also extracted from DEM was aspect and listed from, flat $(-1)$ to the north (360). The last parameter that was converted to the raster map was the Geological map and classified into 7 types. In linear and grid analysis, the following is developed:

- The Euclidean Distance function has been used which provides a geographical precinct or sphere of control to a particular object on the earth's surface over the area surrounding it

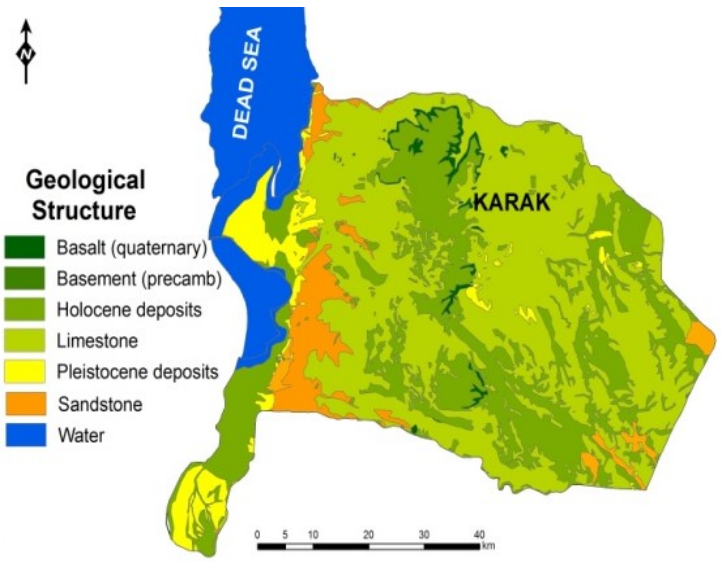

Soil Type (USDA2)

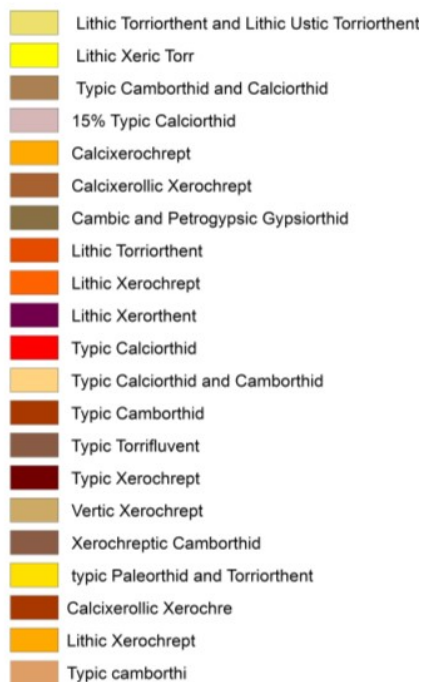

pic camborthi 
- Overlay Weight function can connect all the factors and variables that influence the identification of the best sites by analysis and collection of their weights. Two maps were produced, equal weights were taken on the first map. Based on the previous results from the first map, a different map was created, and higher weights were given to specific factors based on previous studies and the importance of the factor from the point of view of the researchers

The assignment of integrated weights was dictated according to their suitability as a product of the weights assigned to the different layers. Higher weights are given to the residential, location of existing landfills, land use, and water body. This method allows for more flexible combination of different parameters and weights. The weighted suitability technique is designed using GIS to suggest sites suitable for applying the target objective on a variety of thematic levels and based on the Multi-Criteria Assessment theory. Each raster map is reclassified by weight according to the importance of each unit and finally compute the final weight by adding them to extract the approximate values for each position, this can be described by Equation 2(Eastman, 2001).

$$
S=\sum W i \times X i
$$

Where:

Equation 2

$\mathrm{Wi}=$ The weight of ith factor

$\mathrm{Xi}=$ Criteria score of ith factor

$\mathrm{S}=$ Suitability index

In this study, the total weight model is interpreted as shown below in Eq.3 (the total weights must be equal to $100 \%$ as shown in Table 6.

$$
S M=10 X 1+9 X 2+4 X 3+7 X 4+10 X 5+8 X 6+5 X 7+8 X 8+8 X 9+6 X 10+6 X 11+4 X 12+5 X 13+2 X 14+8 X 15
$$

Where:

$\mathrm{X}=$ The weight of factor

$\mathrm{SM}=$ Suitability model in the map

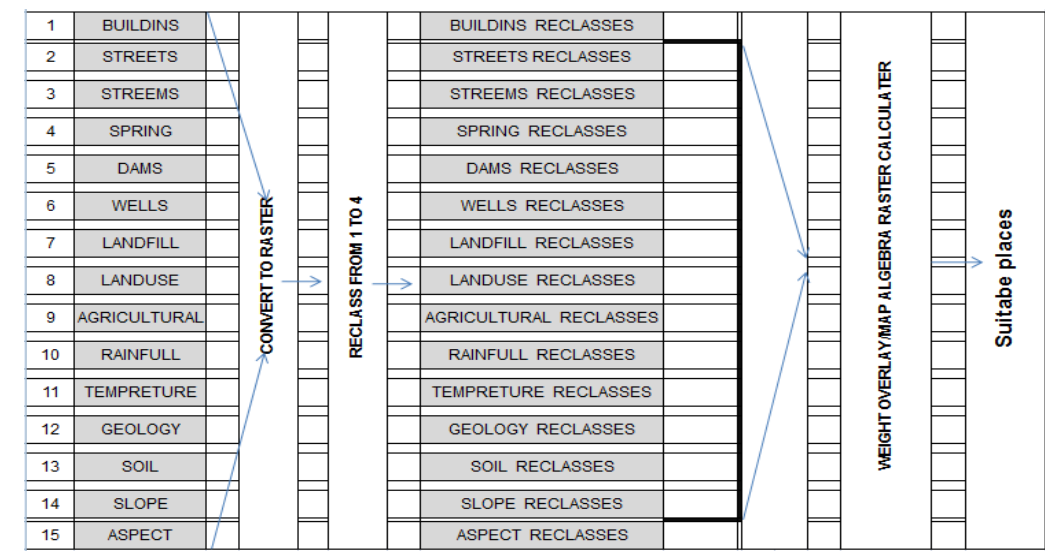

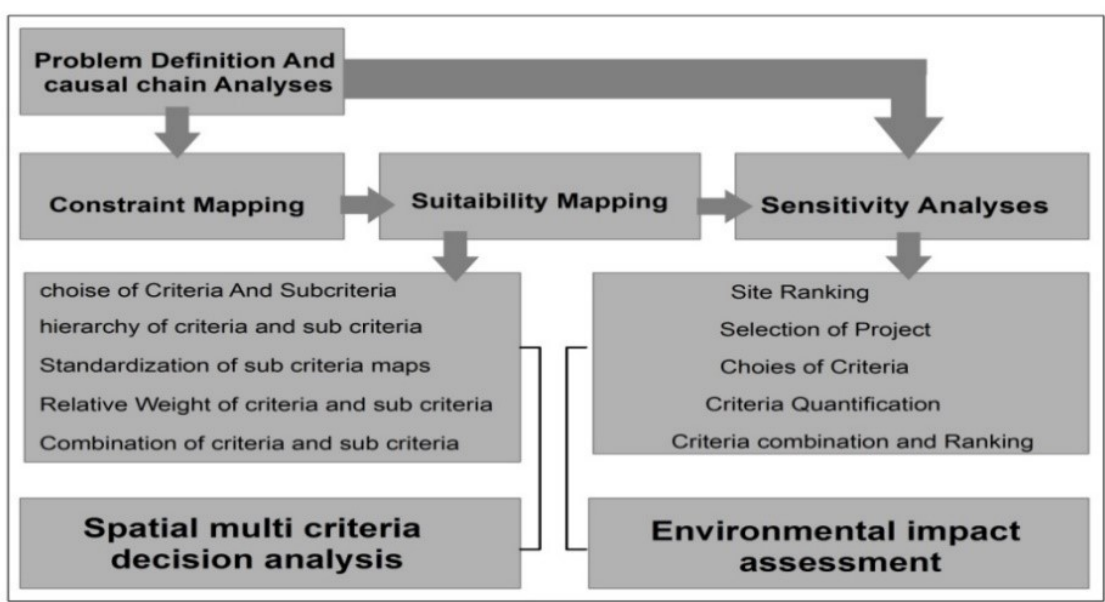

Figure 5: Flow charts of the study 
Table 6: The relative weight of the major factors

\begin{tabular}{|c|c|c|c|}
\hline No & Factors & Sub- Factors & Weight Overlay 100 \\
\hline $\mathrm{X} 1$ & \multirow{5}{*}{$\begin{array}{l}\text { Social and } \\
\text { economic } \\
\text { criteria }\end{array}$} & Buildings & 10 \\
\hline $\mathrm{X} 2$ & & Land use & 9 \\
\hline $\mathrm{X} 3$ & & Agricultural & 4 \\
\hline $\mathrm{X} 4$ & & Streets & 7 \\
\hline $\mathrm{X} 5$ & & Landfill & 10 \\
\hline $\mathrm{X} 6$ & \multirow[t]{4}{*}{ Ecology criteria } & Dams & 8 \\
\hline $\mathrm{X} 7$ & & Wells & 5 \\
\hline $\mathrm{X} 8$ & & Spring & 8 \\
\hline $\mathrm{X} 9$ & & Streams & 8 \\
\hline $\mathrm{X} 10$ & \multirow{3}{*}{$\begin{array}{l}\text { Climatology } \\
\text { criteria }\end{array}$} & Aspect & 6 \\
\hline $\mathrm{X} 11$ & & Rainfall & 6 \\
\hline $\mathrm{X} 12$ & & Temperature & 4 \\
\hline $\mathrm{X} 13$ & \multirow[t]{3}{*}{ Geology criteria } & Geology & 5 \\
\hline $\mathrm{X} 14$ & & Soil & 2 \\
\hline $\mathrm{X} 15$ & & Slope & 8 \\
\hline
\end{tabular}
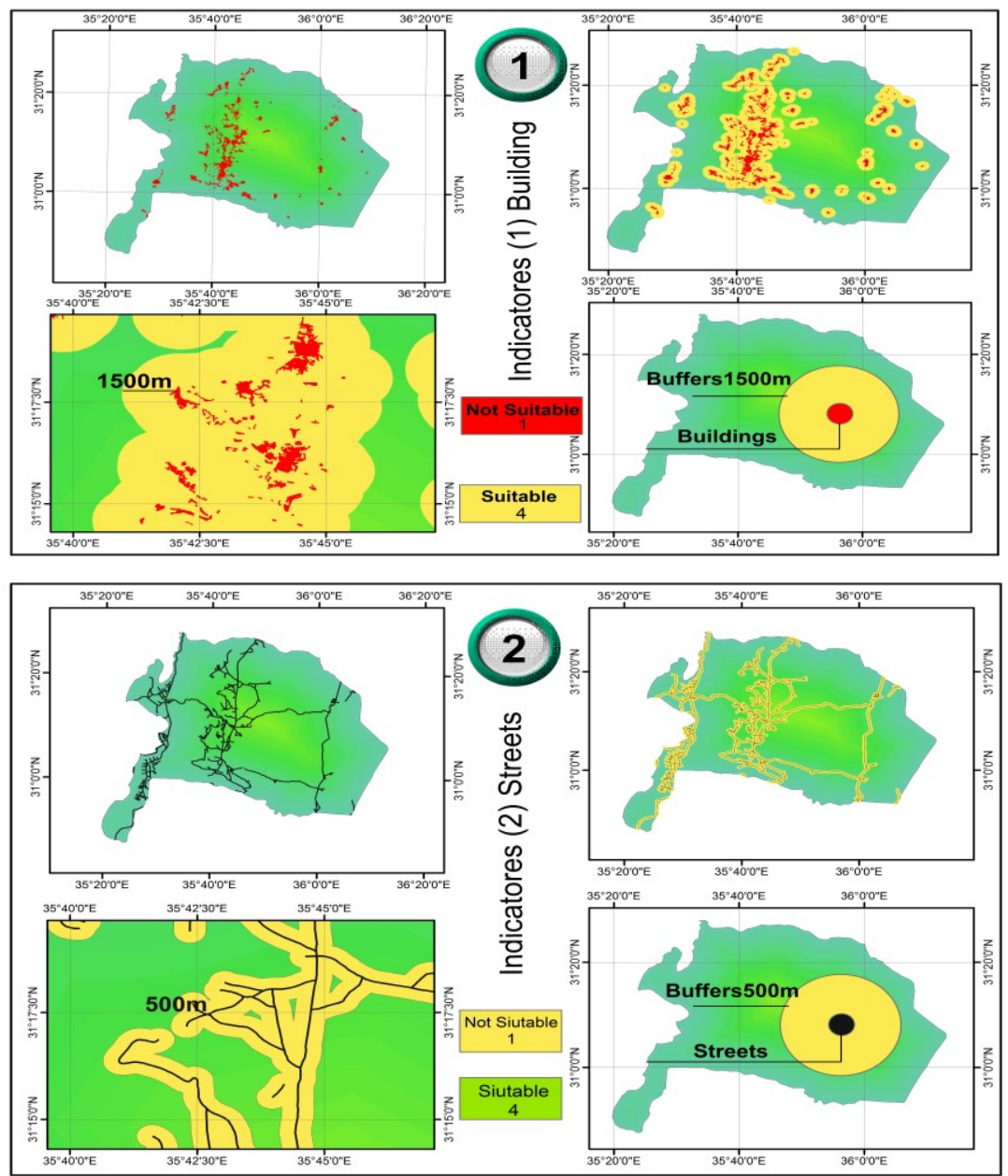

Figure 6: Buffer Raster for Population and Roads 


\subsection{Buffering Map Zone}

A buffer area is a protected area that can reduce the effect on delicate areas or natural features of land use activities separated by grade (Alkaradaghi et al., 2019). Proximity Analysis was used to establishing buffer zone maps for all criteria except slope, Soil, Geology, rain, temperature, and aspect. A distance equal to $1500 \mathrm{~m}, 500 \mathrm{~m}$ from the margins of residential and road was performed as demonstrated in Figure 6. A buffer zone of $1500 \mathrm{~m}$ was given to existing dumpsites as shown in Figure 7. The other parameters (agricultural land, green areas, rain, Temperature, Geology, soil, and slope) were classified according to the graduated color from 1(not suitable) to 4(suitable) as stated in Figure 8.

\section{Result}

The purpose of this study was to assess the current landfill sites in the studied city and to determine the optimal sites for new landfills. 15 standards were used to identify the best location. All requirements were displayed as a digital map. These criteria were generated using Map Algebra from Spatial Analyst Tools in order to extract the final map. The final map was classified into four classes distributed from not suitable to very suitable. Figure 9 identifies the suitability of landfill sites in the city by an equivalent weight for each factor. To achieve the final map form, a group of standardized maps has been integrated with specific requirements. Red circles in the figure below presented the location of the existing landfills. A new map was generated using various weights for factors as seen in Figure 10. The results indicated significant differences between two maps, the proportion of very suitable and not suitable fractions in equal relative weight are more than different relative weight technique.

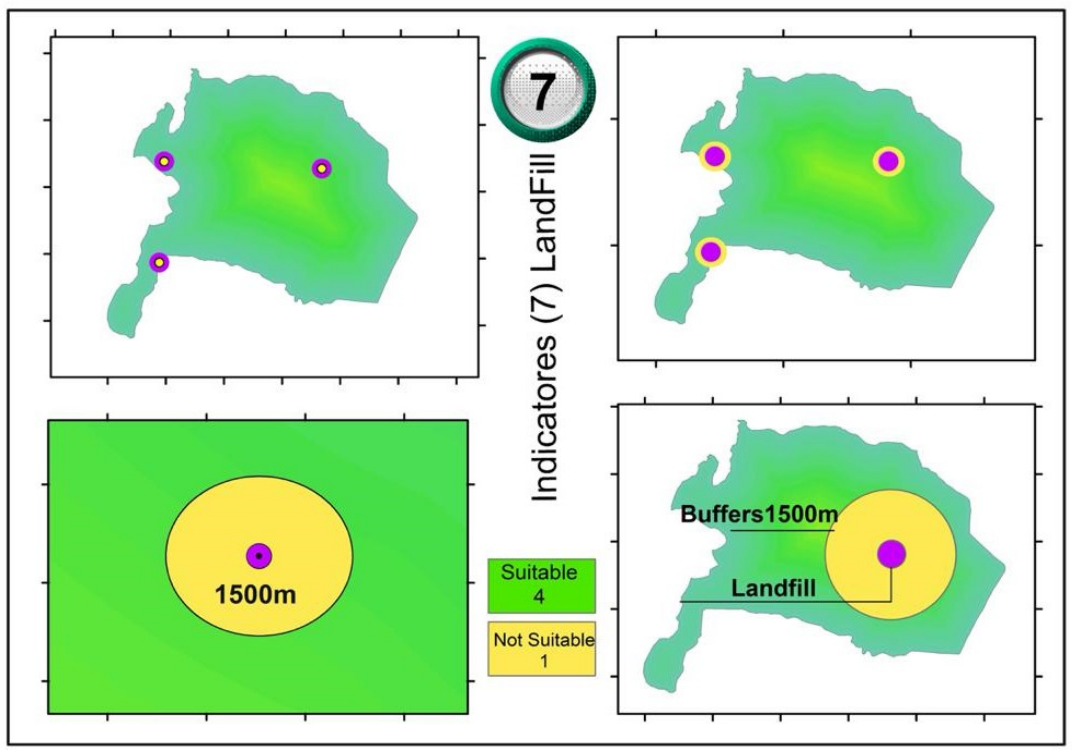

Figure 7: Buffer raster for existing dumpsites
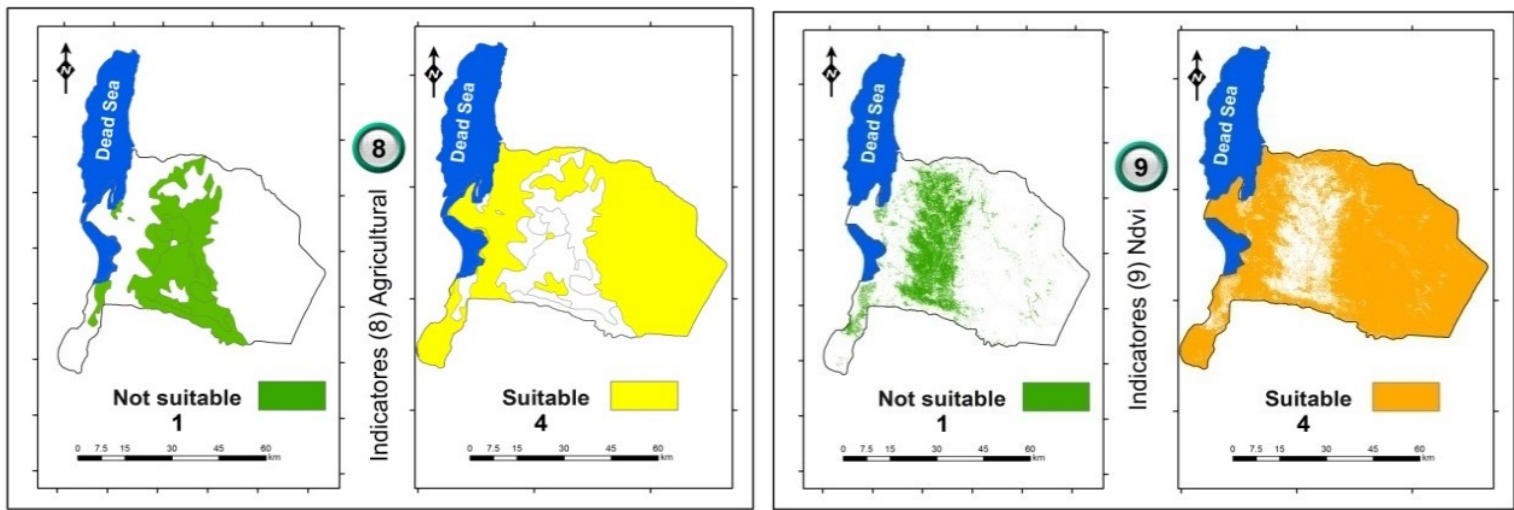

Figure 8: Graduated raster maps accodeing to their sutability (continue next page) 

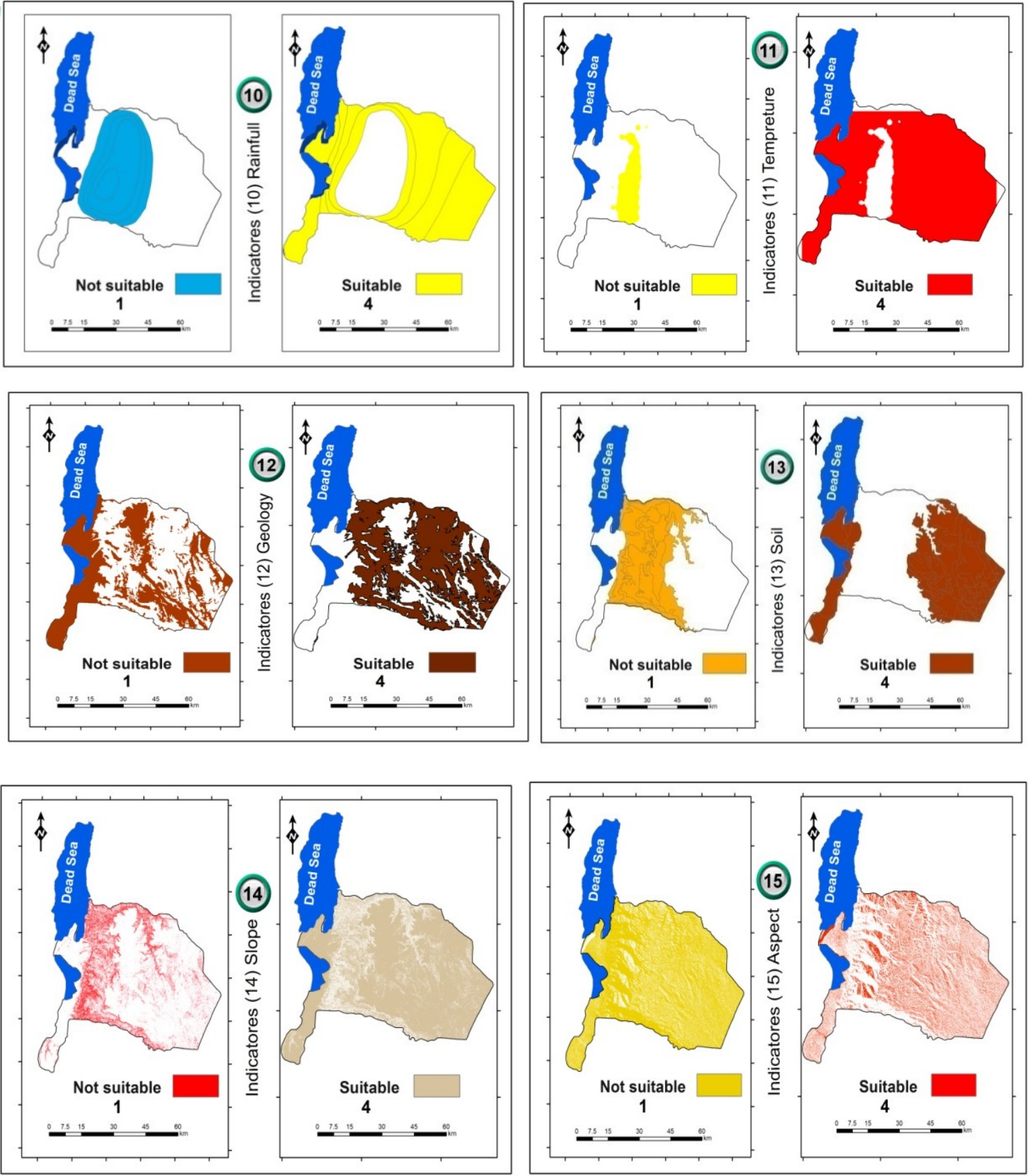

Figure 8: Graduated raster maps accodeing to their sutability 


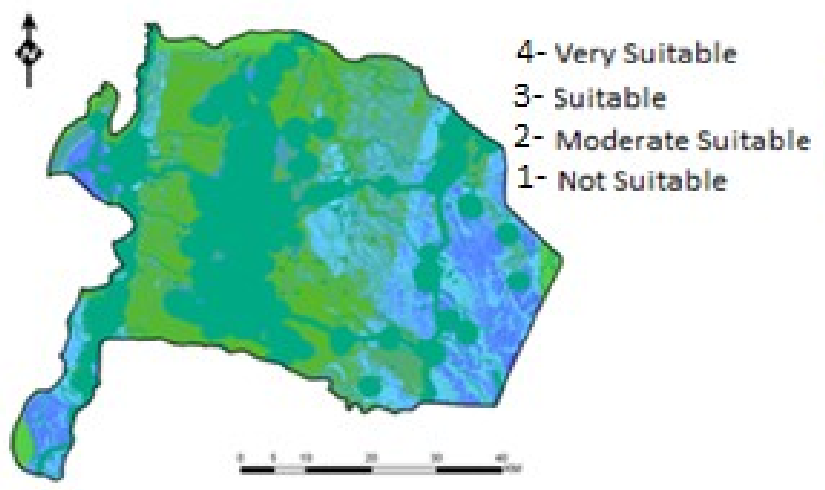

Figure 9: Final suitability map based on equal weights

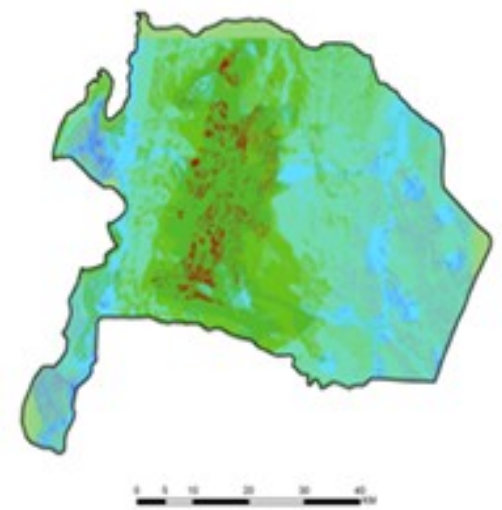

4- VERY SUITABLE

3- SUITABLE

2- MODERATE SUITABLE

1- NOT SUITABLE

Figure 10: Final suitability map based on different weights

Table 7: Areas according to DOS

\begin{tabular}{|c|c|c|c|c|}
\hline Suitability & $\begin{array}{c}\text { Area (equal } \\
\left.\text { weight) } \mathbf{( k m}^{\mathbf{2}}\right)\end{array}$ & Ratio (\%) & $\begin{array}{c}\text { Area (non equal } \\
\text { weight)(km2) }\end{array}$ & Ratio(\%) \\
\hline Very suitable & 259.287 & 7.36 & 204.91 & 5.82 \\
\hline Suitable & 490.088 & 13.92 & 1928.98 & 54.78 \\
\hline Moderate suitable & 1193.329 & 33.89 & 1248.40 & 35.45 \\
\hline Not suitable & 1578.795 & 44.83 & 139.21 & 3.95 \\
\hline
\end{tabular}

This demonstrates the deviation in accuracy among the two strategies in suitability models. According to Table 7, the areas classified as very suitable for a landfill in the equal and non-equal weights maps are approximately close $(7 \%, 6 \%)$ respectively. Also, in the moderate suitable class, the ratios are also slightly close $(34 \%, 35 \%)$. But the major difference is in suitable and non suitable portion as the divided proportion of suitable class between non-equal and equal weights maps is $4 \%$ and $0.09 \%$ of the non suitable class. Every current landfill in the city was scaled according to their location in suitability maps as illustrated in Tables 8-10. From Table 8, the nearest spring appears to be the Allajoun spring (7 $\mathrm{km})$, the nearest dam is Lajjun dam $(24 \mathrm{~km})$ while the closest dam after Lajjun dam is Al-Mujib dam and is even further $(28 \mathrm{~km})$, and Allajoun well further away $(0.4 \mathrm{~km})$. From Table 9, it reveals that the closest spring is Ain-Alrushha spring and is located roughly $(4.5 \mathrm{~km})$. Also, the nearest dam is the Lajjun dam $(6.9 \mathrm{~km})$ and the nearest well is Karim Al-Majali well $(3.2 \mathrm{~km})$. Finally, Table 10 determines the location of the landfill site of Alsomer, the nearest spring is Umm-Hakim Spring $(3 \mathrm{~km})$, the nearest dam is Wadi-Nkheleh $(16 \mathrm{~km})$, the nearest well located $(2.2 \mathrm{~km})$ and at present, it's an unused well, but the distance from working well is $(3.4 \mathrm{~km})$. Proposed sites of the landfill were suggested in UTM ZONE 36 projection system (Figure 11), site 1 coordinates are $X=794385.2931$, and $\mathrm{Y}=3443730.033$, and site 2 coordinates are $X=727601.5225$, and $Y=3419419.5986$. Suitability classes of proposed landfills are shown in Table 11. 
Table8: Class of suitability according to classification for allajoun landfill

\begin{tabular}{|l|c|c|}
\hline \multicolumn{1}{|c|}{ Criteria } & Value & DOS \\
\hline Distance from residential areas & $7130 \mathrm{~m}$ & 4 \\
\hline Distance from main roads and streets & $1402 \mathrm{~m}$ & 4 \\
\hline Distance from valleys and torrents & $2980 \mathrm{~m}$ & 4 \\
\hline Distance from springs & $7410 \mathrm{~m}$ & 4 \\
\hline Distance from dams & $23870 \mathrm{~m}$ & 4 \\
\hline Distance from wells & $415 \mathrm{~m}$ & 4 \\
\hline Distance from existing dumps & $43180 \mathrm{~m}$ & 4 \\
\hline Distance from agricultural land & $9420 \mathrm{~m}$ & 4 \\
\hline Distance from green areas and gardens & $6390 \mathrm{~m}$ & 4 \\
\hline Amount of rain & $150-200 \mathrm{~mm}$ & 4 \\
\hline Temperature & $32-33^{\circ}$ & 2 \\
\hline Geology of the region & Limestone & 3 \\
\hline Soil & $2-12.7 \%$ & 3 \\
\hline Slope & $15 \%$ & 3 \\
\hline Mountain slopes direction(Angle) & $36.57^{\circ}$ & 3 \\
\hline
\end{tabular}

Table 9: Class of suitability according to classification for albrekalandfill

\begin{tabular}{|l|c|c|}
\hline \multicolumn{1}{|c|}{ Criteria } & Value & DOS \\
\hline Distance from residential areas & $3150 \mathrm{~m}$ & 4 \\
\hline Distance from main roads and streets & $578 \mathrm{~m}$ & 4 \\
\hline Distance from valleys and torrents & $4230 \mathrm{~m}$ & 4 \\
\hline Distance from springs & $4550 \mathrm{~m}$ & 4 \\
\hline Distance from dams & $6920 \mathrm{~m}$ & 4 \\
\hline Distance from wells & $3220 \mathrm{~m}$ & 4 \\
\hline Distance from existing dumps & $28110 \mathrm{~m}$ & 4 \\
\hline Distance from agricultural land & $3580 \mathrm{~m}$ & 4 \\
\hline Distance from green areas and gardens & $2590 \mathrm{~m}$ & 4 \\
\hline Amount of rain & $50-100 \mathrm{~mm}$ & 4 \\
\hline Temperature & $38-39^{\circ}$ & 4 \\
\hline Geology of the region & Holocene deposits-Pleistocene deposits & 2 \\
\hline Soil & $3.2^{\circ} \%$ & 4 \\
\hline Slope & $263^{\circ}$ & 4 \\
\hline Mountain slopes direction(Angle) & & 1 \\
\hline
\end{tabular}

Table 10: Class of suitability according to classification for alsomer landfill

\begin{tabular}{|l|c|c|}
\hline \multicolumn{1}{|c|}{ Criteria } & Value & DOS \\
\hline Distance from residential areas & $3930 \mathrm{~m}$ & 4 \\
\hline Distance from main roads and streets & $1370 \mathrm{~m}$ & 4 \\
\hline Distance from valleys and torrents & $2550 \mathrm{~m}$ & 4 \\
\hline Distance from springs & $2840 \mathrm{~m}$ & 4 \\
\hline Distance from dams & $15940 \mathrm{~m}$ & 4 \\
\hline Distance from wells & $3420 \mathrm{~m}$ & 4 \\
\hline Distance from existing dumps & $27910 \mathrm{~m}$ & 4 \\
\hline Distance from agricultural land & $1000 \mathrm{~m}$ & 3 \\
\hline Distance from green areas and gardens & $1045 \mathrm{~m}$ & 3 \\
\hline Amount of rain & $50-100 \mathrm{~mm}$ & 4 \\
\hline Temperature & $37-40^{\circ}$ & 4 \\
\hline Geology of the region & Holocene deposits-Pleistocene deposits & 2 \\
\hline Soil & $<2 \%$ & 4 \\
\hline Slope & $7.93 \%$ & 3 \\
\hline Mountain slopes direction(Angle) & $214^{\circ}$ & 1 \\
\hline
\end{tabular}




\section{Discussion}

The landfill is the most commonly used method in the world for final disposal of MSW, due to its low cost (Babalola and Busu, 2011) But, this is really a difficult step because it relies on different criteria and factors to establish safe sites of waste (Alabdraba and Khudhair, 2011). The purpose of the current study is to review the existing sites and suggest new sites with different criteria.

The weighted overlay model was used in analyzing the decision in GIS and to present the maps. Multiple explained conditions were identified by adopting a multi-criteria strategy. The decision of new sites of the landfill was based on the results of two maps. The first map demonstrates the suitability sites according to the same scale for each factor while the final map overlays the factors with different measurement scales depending on its importance. Both maps show areas with various degrees of suitability for dumping in the studied area. The outcome is affected by different conditions in weighted overlays. So, all related factors in effecting landfill sites would be important to measure and classify preferred values. The map output of similar weight analysis identifies a suitable region for landfills along the northeasternside of the city. This is not quit $\mathrm{e}$ unlikely because those regions are not agricultural lands. While the same class is distributed along eastwest of the city in different weights map. The current study found that $45 \%$ of the area is not suitable for landfills while only $4 \%$ of the same area is not suited by using overlay weight methods. The significant differences are occurred in class 3(suitable) and 1(not suitable) according to calculated Equation 4:

$$
\text { Difference }=\frac{\text { Area } 1-\text { Area } 2}{\text { TotalArea }} * 100 \%
$$

Equation 4

Where:

Difference $=$ The difference in areas between two used method(equal and non equal weight) in the same class

Area $1=$ The area in class $(1,2,3$, and 4$)$ as described in Figure 11 for non equal weight map

Arae $2=$ The area in class $(1,2,3$, and 4$)$ as described in Figure 12 for equal weight map

Total Area $=$ The total area of the studied city $\left(3521.5 \mathrm{~m}^{2}\right)$

The outcomes of using the above equation are shown in Figure 12, the big negative difference in class $1(41 \%)$ is due to the small relative weight given to soil factor; this reflects the fact that soil is a very important and dominant factor in the selection of landfill sites in Jordan and in internationally whereas other parameters such as distance from residential areas and distance from existing dumpsites, which are two very important factors particularly locally, may make a positive difference $(41 \%)$. The temperature parameter is very suitable for Albreka and Alsomer landfills but moderate suitable for the Allajoun landfill. The rain parameter has only been appropriate for Albreka and Alsomer landfills and the wind direction criteria have been perfect for Albreka landfill only, moderate suitable for Alsomer landfill, and not suitable for the Allajoun landfill. The DOS in the direction of the Allajoun mountain slope is low, which can be concluded from unpleasant odors surrounding the area, especially since this region receives numerous complaints from citizens and road users in this region. Geological parameters for all existing dumpsites are moderately appropriate, except for Allajoun landfills which exist on a limestone geological site. Lime can provide a useful chemical barrier to particular pollutants being transported as the limestone-soil mixture was used in designing landfills (Malone and May, 1987). In the recent process-integrated method used by Reich who proved that mixing hazardous waste with lime lead to different compounds with different solubility (Reich et al., 2002). Holocene-Pleistocene deposits geology lands existing in Albreka and Alsomer landfill are considered as sediments and a crust of fine sand that contains not only Glaciomarine deposits but also moderate marine sediment. The soil of Allajoun landfills varied between TypicVertic Xerochrept which is considered as semi-dry soils that reduce leakage. The soil of Albreka landfill varied between Typic-Typic Xerochrept which is considered as a type of shallowsurface $s$ richwithsilt and mud, and also reduces leakage. Alsomer landfill soil varied between Typic-Vertic Xerochrept ranges between low to medium permeability. To confirm the accuracy of the results; Abu-El-Sha'r et al., 2001 found that the general condition of landfills in Al-karak city is bad and this due to several reasons such as possible groundwater pollution, rodent spread, and bad odours. The authors suggested that liquid should separate from solid waste and establish a treatment plan. Also, AL-Husban., 2019 recommended that an appropriate design should set for future landfills. Another research concluded that landfill design in Jordan should take into account accurate precipitation date, wind direction, temperature, location from water body and residential areas (Aljaradin and Persson, 2012). 

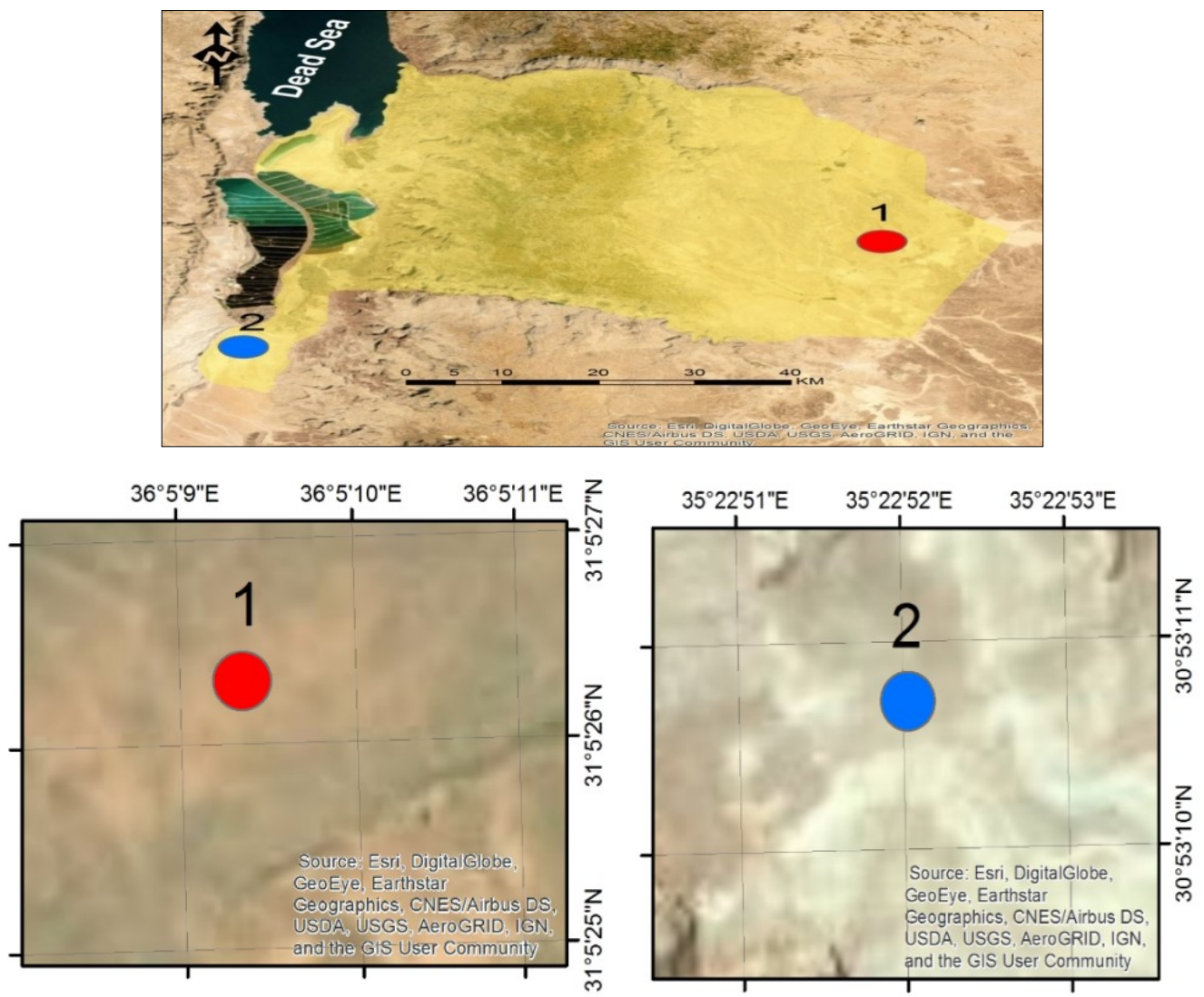

Figure 11: Locations of proposed sites

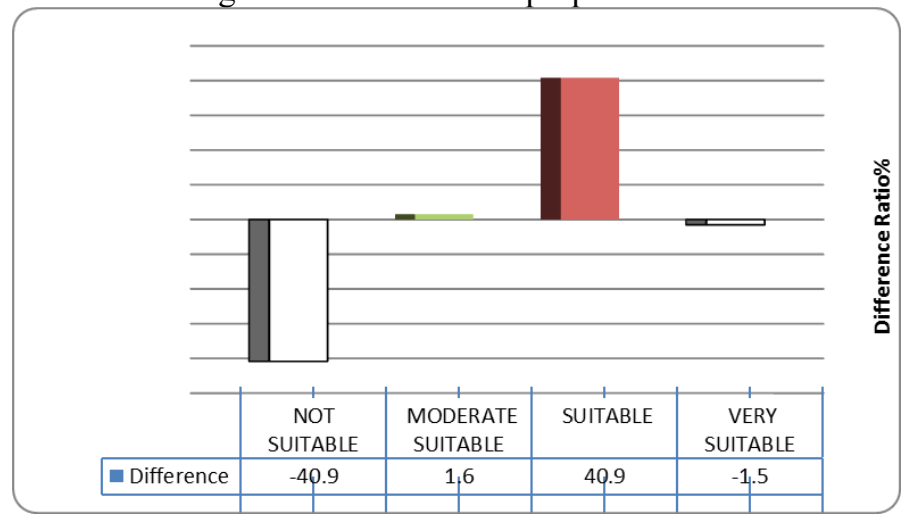

Figure 12: The Differences in areas according to suitability classes

\section{Conclusion and Recommendation}

The setting of landfills in Al-Karak city cannot generally be judged, but all criteria must be examined to determine the defects. The majority of requirements to be evaluated have also been analyzed to assess the nature of existing sites and to recommend locations that are more suited for environmental protection and better than those exist already. By using two integrated technique, the first suitability map (equal weight) showed that only $7 \%$ is very suitable and $45 \%$ is not suitable for dumping sites. The second suitability map (non-equal weight) presented that only $6 \%$ is very suitable and only $4 \%$ is not suitable. Although the highest percentage of over half (55\%) was found in the last map related to the suitable class. The average amount of precipitation and distances from residents, main roads, water body, existing dumps, land use, and green areas were perfect (DOS=4) for all existing waste dumps. Also, temperature criteria registered excellent ranks for two existing landfills and the third (Allajoun landfill) scaled at a low rank $(\mathrm{DOS}=2)$. Geology criteria were on average between limestone -Holocene-Pleistocene deposits land $(\mathrm{DOS}=2,3)$. The significant negative effect on 
the scale was for wind direction criteria. In particular, the soil factor plays an important role in deciding the suitable areas, so it is advisable to give the soil parameter greater weight in future research. The accuracy between equal and non-equal overlay weight existed in not suitable areas, as the percentage was higher in the equal suitable map. This reflects that both approaches have different outcomes and that their adoption depends on the researchers' views, the nature of the field, and the factors introduced.

Two sites were proposed, the first located in Northeast of the city and the second in the Southwest of the city. Both locations meet appropriate standards $(\mathrm{DOS}=3,4)$. For the three existing landfills, environmental protection steps are recommended to minimize the harmful effects of the burial process on the nearby residents; as Dutta and V (Dutta et al., 2012a) have pointed out that the dust can be tackled with water spray, regardin gthe problems of disposing of insects, rats, mosquitoes and rodents, by placing a daily cover and eliminating standing water. The long-term environmental plan also is important to avoid released contaminants (Dutta et al. 2012b).

\section{References}

Abu-El-Sha'r, W., Chopra, M. and Reinhart, D., 2001, US-Jordan Municipal Solid Waste Management Collaborative Research. The National Science Foundation, 4201 Wilson Boulevard Arlington, VA 22230 , University of Central Florida, Orlando, FL and Jordan University of Science and Technology.

AL-Husban, Z., 2019, Environmental and Economic Evaluation for Biogas Generation in Jordan as a Greenhouse Gas Mitigation Option. Journal of Petroleum \& Environmental Biotechnology, Vol. 10, 392, DOI:10.35248/2157-7463.19.10.392.

Aljaradin, M., 2010, Municipal Solid Waste Landfills in Jordan-Current Conditions and Prospective Future. $1^{\text {st }}$ International Conference on Final Sinks. Vienna University of Technology, Institute for Water Quality, Waste and Resources Management.

Aljaradin, M. and Persson, K., 2012, Environmental Impact of Municipal Solid Waste Landfills in Semi-Arid Climates - Case Study - Jordan. The Open Waste Management Journal, Vol.5, 28-39.

Akbari, V., Rajabi, M., Shams, R. and Chavoshi, S., 2008, Landfill Site Selection By Combining GIS and Fuzzy Multi Criteria Decision Analysis, Case Study: Bandar Abbas, Iran. World Applied Sciences Journal, Vol. 31, 39-47.
Alabdraba, W. and Khudhair, H., 2011, Selecting Best Landfill Site for Solid Waste in the City of Tikrit Using GIS Tools. The Second Conference of Environmental Studies at: Environmental Research Center. https://doi.org/10.13140/RG.2.1.1928.4968.

Alanbari, M., Al-Ansari, N., Jasim, H. and Knutsson, S., 2014, Al-Mseiab Qadaa Landfill Site Selection Using GIS and Multicriteria Decision Analysis. Engineering. Vol. 6, 526549. http://dx.doi.org/10.4236/eng.2014.69055.

Al-Ansari, N., Al- Hanbali, A. and Knutsson, S., 2012, Locating Solid Waste Landfills in Mafraq City, Jordan. Journal of Advanced Science and Engineering Research, Vol. 2, 40-51.

Alkaradaghi, K., Ali, S., Al-Ansari, N., Laue, J. and Chabuk, A., 2019, Landfill Site Selection Using MCDM Methods and GIS in the Sulaimaniyah Governorate, Iraq. Sustainability, 11, 4530. https://doi.org/10.3390/su11174530.

Babalola, A. and Busu I., 2011, Selection of Landfill Sites for Solid Waste Treatment in Damaturu Town-Using GIS Techniques. Journal of Environmental Protection (JEP), Vol. 2, 110.https://doi.org/10.4236/jep.2011.21001.

Barakat, A., Hilali, A., Baghdadi, M. and Touhami, F., 2017, Landfill Site Selection with GIS-Based Multi-Criteria Evaluation Technique. A Case Study in Be'ni Mellal-Khouribga Region, Morocco. Environ Earth Sci., Vol. 76, 413. https://doi.org/10.1007/s12665-017-6757-8.

BCRC-Cairo, 2005a, Preparation of a Set of Tools for the Selection, Design and Operation of Hazardous Waste Landfills in Hyper-Dry Areas. Regional Center for Training and Technology Transfer for the Arab State, Annex (2).

BCRC-Cairo, 2005b, Preparation of a Set of Tools for the Selection, Design and Operation of Hazardous Waste Landfills in Hyper-Dry Areas, Regional Center for Training and Technology Transfer for the Arab State, Section 4.1.3 Public Acceptance Criteria, 1-14.

Bilintoh, T. M. and Stemn, E., 2015, Municipal Solid Waste Landfill Site Selection in the Sekondi-Takoradi Metropolis of Ghana Using Fuzzy Logic in a GIS Environment. Journal of Environment and Waste Management, Vol. 2, 071-078.

Carvalho, L., Ribeiro., M., Oliveira, L., Oliveira, T., Louzada, J., Scolforo, J. and Oliveira, A., 2007, Weighted Overlay, Fuzzy Logic and Neural Networks for Estimating Vegetation Vulnerability within the Ecological Economical Zoning of Minas Gerais, Brazil. IX Brazilian Symposium on GeoInformatics. 171-182. 
Department for Environment, Food and Rural Affairs, (2010), Environmental Permitting Guidance the Landfill Directive. http://www.defra.gov.uk/environment/policy/permits.

Dutta, V., 2012a, Landfill Planning and Design Considerations. Guru Nanak Dev Engineering College, Ludhiana (Punjab), India (2011), page 71.

Dutta, V., 2012b, Landfill Planning and Design Considerations. Guru Nanak Dev Engineering College, Ludhiana (Punjab), India (2011), page 12.

Eastman, R. J., 2001, IDIRISI Andes: Guide to GIS and Image Processing, Clark University, USA, 144.

EcoMENA, 2012, Solid Waste Management in Jordan. https://www.ecomena.org/swm-jordan/ (accessed 31 March 2019).

Ekmekçioglu, M., Kaya, T. and Kahraman, C., 2010, Fuzzy Multicriteria Disposal Method and Site Selection for Municipal Solid Waste. Waste Management, Vol. 30, 1729-36. -https://doi.org/10.1016/j.wasman.2010.02.031.

Eskandari, M., Homaee, M., Mahmoodi, S., Pazira, E. and Genuchten, M., 2015, Optimizing Landfill Site Selection by Using Land Classification Maps. Environ. Sci. Pollut. Res., Vol. 22, 7754-7765. https://doi.org/10.1007/s11356-015-4182-7.

Jerie, S., 2017, Site Suitability Analysis for Solid Waste Landfill Site Location Using Geographic Information Systems and Remote Sensing: A Case Study of Banket Town Board, Zimbabwe. Review of Social Sciences, Vol. 2(4). https://doi.org/10.18533/rss.v2i4.99.

Jordan Green Buildings Council, 2009, Your Guide To Waste Management in Jordan. https://library.fes.de/pdf-

files/bueros/amman/12729. (accessed 2016).

Khorram, A., Yousef, M., Alavi, S. and Farsi, J., 2014, Convenient Landfill Site Selection by Using Fuzzy Logic and Geographic Information Systems: A Case Study in Bardaskan, East of Iran, 4, e19383.

Kuru, A. and Terzi, F., 2018, Determination of New Deveploment Area in Kirklareli by GIS Based Weighted Overlay Analysis. International Journal of Environment and Geoinformatics (IJEGEO), Vol. 5(3), 2148-9173.

Malone, P. and May, J., 1987, Use of Lime in the Design of Landfills for Waste Disposal in Lime for Environmental Uses, 42-51. https://doi.org/10.1520/STP23150S.

Manoiu, V., Fontanine, I., Costache, R., Pravalie, R. and Mitof, I., 2013, Using GIS Techniques for Assessing Waste Landfill Placement Suitability.
Case study: Prahova County, Romani. Geographia Technica, Vol. 18, 47-56.

Meirelles, M. S. P., Moreira, F. R. and Camara, G., 2007, Técnicas de Inferência Espacial, Geomática: Modelos E Aplicações Ambientais, Meirelles, M. S. P.; Camara, G.; Almeida, C. M. Brasília: EMBRAPA. 107-189.

Mussa, A. and Suryabhagavan, V. K., 2019, Solid Waste Dumping Site Selection Using GIS-Based Multi-Criteria Spatial Modeling: A Case Study in Logia Town, Afar Region, Ethiopia. Journal Geology, Ecology, and Landscapes, 1-13, https://doi.org/10.1080/24749508.2019.1703311

Pasalari, H., Nodehi, R., Mahvi, A., Yaghmaeian, K. and Charrahi, Z., 2019, Landfill Site Selection Using a Hybrid System of AHP-fuzzy in GIS Environment: A Case Study in Shiraz City, Iran. MethodsX, Vol. 6, 1454-1466, https://doi.org/10.1016/j.mex.2019.06.009.

Pla, M., 2015, Field Research Working Paper Municipal Solid Waste Management in Beijing, China. Asian Metropolis. https://doi.org/10.13140/RG.2.1.3888.3287.

Reich, J., Pasel, C., Herbell, J. D. and Luckas, M., 2002, Effects of Limestone Addition and Sintering on Heavy Metal Leaching from Hazardous Waste Incineration Slag. Waste Manag., Vol. 22, 315-26. https://doi.org/10.1016/s0956-053x(01)00020-4.

Saaty, T., 2008, Decision making with the Analytic Hierarchy Process. International Journal of Services Sciences, Vol. 1, 83-98. https://doi.org/10.1504/IJSSCI.2008.017590.

Sekulovic, D. and Jakovljevic, G., 2016, Landfill Site Selection Using GIS Technology and the Analytic Hierarchy Process. Military Technical Courier, Vol. 64, 769-783. https://doi.org/10$.5937 /$ vojtehg64-9578.

Sener, S., Sener, E., Nas, B. and Karagüzel, R., 2010, Combining AHP with GIS for Landfill Site Selection: A Case Study in the Lake Beyşehir Catchment Area (Konya, Turkey). Waste Manag., Vol. 30, 2037-46, https://doi.org/10.1016/j.wasman.2010.05.024.

Shahabi, H., Keihanfard, S., Ahmad, B. and Amiri, M., 2014, Evaluating Boolean, AHP and WLC Methods for the Selection of Waste Landfill Sites Using GIS and Satellite Images. Environmental Earth Sciences., Vol. 71, 42214233.

The European Bank For Reconstruction And Development (EBRD), 1991, Osh and JalalAbad Solid Waste Management - Environmental and Social Due Diligence. https://www.eib.org- 
/attachments/registers/54495969/

(accessedNovember 2013).

Vasiljevic, T., Srdjevic, Z., Bajčetić, R. and Miloradov, M., 2012, GIS and the Analytic Hierarchy Process for Regional Landfill Site Selection in Transitional Countries: A Case Study From Serbia. Environ Manage., Vol. 49, 445-58, https://doi.org/10.1007/s00267-0119792-3.

Yazdani, M., Monavari, S., Omrani, G., Shariat, M. and Hosseini, S., 2015, Landfill Site Suitability Assessment by Means of Geographic Information System Analysis. Solid Earth, Vol. 6, 945-956. https://doi.org/10.5194/se-6-945.
Yesilnacar, M., Suzen, M., Kaya, B. and Doyuran, V., 2011, Municipal Solid Waste Landfill Site Selection for the City of Şanliurfa-Turkey: An Example Using MCDA Integrated with GIS. International Journal of Digital Earth. Vol. 5, 147-164. https://doi.org/10.1080/17538947.2011.583993.

Younes, M., Basri, A., Nopiah, Z., Basri, H. and Abushammala, M., 2015, Use of a Combination of MRSS-ANP for Making an Innovative Landfill Siting Decision Model. Mathematical Problems in Engineering, Vol. 3, 1-13. https://doi.org/10.1155/2015/381926. 